Xu, J., \& Liu, F. (2020). The Impact of Intellectual Capital on Firm Performance: A Modified and

Extended VAIC Model. Journal of Competitiveness, 12(1), 161-176. https://doi.org/10.7441/joc.2020.01.10

\title{
THE IMPACT OF INTELLECTUAL CAPITAL ON FIRM PERFORMANCE: A MODIFIED AND EXTENDED VAIC MODEL
}

\author{
- Jian Xu, Feng Liu
}

\begin{abstract}
Intellectual capital (IC) is generally understood as an important driver of firm competitiveness improvement and value generation in the knowledge economy. The manufacturing industry, the backbone of the South Korean economy, is coming under increasing international pressure. In order to increase the competitiveness of Korean industry, the main objective of this paper is to examine the impact of IC and its components on the performance of Korean manufacturing firms over the period 2013-2018. The modified and extended Value Added Intellectual Coefficient (VAIC) model was adopted to more accurately measure IC, and firm performance was systematically and comprehensively measured in three distinct parameters: profitability, productivity and market value. Our regression results show that physical capital was the most influential factor to firm performance; human capital was viewed as a performance enhancing measure; structural capital had no significant impact on firm performance; and innovation capital and relational capital hurt a firm's profitability. It is also evident that the modified and extended VAIC model performs better than the original VAIC model proposed by Pulic (1998). This study extends the understanding of IC in achieving a competitive edge in the manufacturing sector, with IC representing a valuable platform for the sustainable development of the manufacturing sector in emerging Asian markets.
\end{abstract}

Keywords: intellectual capital, firm performance, Value Added Intellectual Coefficient (VAIC), manufacturing sector

JEL Classification: O34, G30, L25

Received: November, 2019

1st Revision: February, 2020

Accepted: February, 2020

\section{INTRODUCTION}

In the knowledge economy, intellectual capital (IC) is considered a more important contributor to firms rather than tangible assets in firm competitiveness improvement and value generation (Ahangar, 2011; Hsu \& Chang, 2011; St-Pierre \& Audet, 2011; Jelínková \& Jiřincová, 2015). Based on resource-based theory, the resources possessed by any organization are unique and inimitable (Marr et al., 2003). IC, a relatively new designation as a strategic resource, is related to securing 
a competitive edge and superior performance by value generation (Marr et al., 2003; Clarke et al., 2011). Therefore, it is essential for firms to understand, identify, develop, and utilize IC efficiently, all of which can help firms gain competitive advantage.

The manufacturing industry, as a capital- and knowledge-intensive industry, is the backbone of a nation's economy (Behun et al., 2018). However, this industry has been facing great pressures from domestic and international markets (Herrmann et al., 2014). In 2014, the strategy Manufacturing Innovation 3.0 was released with the goal of improving the overall competitiveness of Korea's manufacturing industry (Xu \& Sim, 2018). The manufacturing sector in South Korea mainly relies on the imports of high-tech production materials from Japan (Fukao et al., 2016). Recently, Japan and South Korea have become engaged in a trade restriction battle which will seriously hinder the sustainable development of Korea's manufacturing sector, especially electronic manufacturing firms. For this and many other reasons, Korean manufacturing firms should seek new ways to obtain a sustainable competitive advantage and improve firm competitiveness by using IC efficiently. In addition, the manufacturing sector has attracted the attention of many scholars in the IC literature (Phusavat et al., 2011; St-Pierre \& Audet, 2011; Andreeva \& Garanina, 2016; Crema \& Verbano, 2016; Delgado-Verde et al., 2016; Molodchik \& Jardon, 2017; Cisneros \& Hernandez-Perlines, 2018; Xu \& Wang, 2018; Bayraktaroglu et al., 2019; Xu \& Li, 2019).

This paper aims to modify and extend the original Value Added Intellectual Coefficient (VAIC) model by introducing two extra components. Our work investigates the effect of IC and its components on the performance of manufacturing firms in the context of South Korea. Firm performance measurement is divided into three categories: profitability, productivity and market value, with results showing that out of four other components, physical capital influences profitability and productivity positively and significantly as does human capital (HC), which also stimulates corporate profits. Innovation capital and relational capital (RC) both have negative impacts solely on a firm's profitability.

The contribution of this paper is presented in four aspects. First, this paper extends IC research by applying the modified and extended VAIC model to more accurately measure IC. This new model consists of two additional IC components, namely, innovation capital and RC. Second, the calculation of value added (VA) is altered based on the idea that proxies of IC components should be treated as investments instead of costs. Research and development (R\&D) expenses as well as marketing and advertising expenses are added back into the VA calculation. Third, this paper adds the macroeconomic indicator to minimize external influences. Finally, this paper can provide insights into the IC-firm performance relationship in emerging Asian economies. Policymakers and corporate managers can use these findings as a starting point to better understand the significance of IC components and their impacts on firm performance, and thus to develop more effective strategies to efficiently manage IC resources to gain competitive advantage.

\section{THEORETICAL BACKGROUND}

\subsection{IC and its measurement}

A relatively new concept, IC has been defined and classified by researchers in various ways. Edvinsson \& Malone (1997) describe IC as encompassing all the experience and skills gained 
by employees and customer relations. One important definition has been proposed by Stewart (1997), who thought that IC comprises knowledge, information, intellectual property and experience that can generate wealth for the firm. The difference between the market value and book value of a firm has also been categorized in terms of IC (Maditinos et al., 2011).

Scholars have classified IC using various components. Brooking (1996) characterized IC as comprising HC, structural capital (SC), market capital, and knowledge property rights capital. Edvinsson \& Malone (1997) classified IC into HC and SC, with HC, the core of IC, referring to the individual tacit knowledge sets, skills, abilities, experiences of employees in an organization (Bontis, 1998; Ngah \& Ibrahim, 2009). HC is the kind of knowledge that is implicit by nature. Knowledge generated by the cooperation of employees or divisions is also included in the definition of HC (Swart, 2006). SC reflects an organization's capabilities, procedures, processes, patents, culture, etc. (Ahangar, 2011). Even if a firm does not possess HC, SC is still stored within the firm (Ngah \& Ibrahim, 2009). Sveiby (1997) has divided IC into HC, SC and customer capital, with customer capital subsequently replaced with RC by some researchers. Stewart (1997) classified IC into HC, SC, and RC. RC contains the value and knowledge from corporate networks among customers, suppliers, distributors, competitors and all other related parties. Nevertheless, customer relations are viewed as the most important component of all (Bontis, 1998). Even though different IC classifications exist, IC is generally conceived as the composition of HC, SC, and RC (Stewart, 1997; Sveiby, 1997; Nimtrakoon, 2015; Xu \& Li, 2019; Xu \& Wang, 2019a; Yao et al., 2019).

Different methods have been developed for measuring IC, such as Tobin's Q, the Skanadia Navigator, the Intangible Assets Monitor, the balanced scorecard approach, market capitalization methods, and the VAIC model. Among them, the VAIC model proposed by Pulic (1998) is broadly used both in academia and practice (Ho \& Williams, 2003; Mohapatra et al., 2019; Xu \& Liu, 2019). VAIC is the sum of three efficiency elements: capital employed efficiency (CEE), human capital efficiency (HCE) and structural capital efficiency (SCE). These calculations are expressed as follows:

$$
\begin{aligned}
& C E E=V A / C E \\
& H C E=V A / H C \\
& S C E=(V A-H C) / V A \\
& V A I C=C E E+H C E+S C E
\end{aligned}
$$

where VA $=$ Operating profit + Depreciation + Amortization + Employees' salaries and wages

$$
C E=\text { Total assets }- \text { Total liabilities }
$$

$H C=$ Employees' salaries and wages

The VAIC model, an indicator-based financial method, is not likely to cause subject bias (Mohapatra et al., 2019). The data in this model are derived from audited financial statements that are publicly available (Clarke et al., 2011). This model also provides information that can be used for comparison across industries (Maditinos et al., 2011).

Nevertheless, the VAIC model has some limitations. For instance, Ståhle et al. (2011) pointed out that it merely focuses on the efficiency of the labor and capital investments of firms rather 
than IC efficiency. The original VAIC model ignores the firm's RC and innovation capital (Ståhle et al., 2011; Smriti \& Das, 2018). Similarly, the measure of SC in the original VAIC model may not be complete (Chen et al., 2005). Nimtrakoon (2015) modified the original VAIC model by introducing market costs as RC. Therefore, to overcome the shortcomings, we have modified and extended the original VAIC model as the measurement of IC.

\subsection{Modified VAIC model}

Some studies have modified the original VAIC model by introducing other IC components that are neglected in Pulic (1998)'s VAIC model. Nazari \& Herremans (2007) replaced SC with customer capital, renewal capital and process capital. They expressed SC as the sum of these three components to further understand IC's role. Customer capital was measured by marketing expenses, and renewal capital was measured by R\&D expenses.

Chang (2007) added innovation capital and intellectual property capital to Pulic (1998)'s VAIC model. Innovation capital is defined as the ability to generate new knowledge based on previous knowledge, and intellectual property capital is referred to as legally protected rights (e.g. patents, copyrights, and trademarks).

Chen et al. (2005) modified the original VAIC model by including two SC sub-components-innovation capital and $\mathrm{RC}-$ as control variables. $\mathrm{R} \& \mathrm{D}$ and advertising expenses were chosen as proxies for relational and innovation capitals. They argued that these expenses should be treated as asset-like investments rather than costs. Similarly, Xu \& Wang (2018) also used the same model in the case of South Korea.

Another modified VAIC model including RC as the new IC component was developed by Vishnu \& Gupta (2014). Marketing, selling and advertising expenses were introduced as the proxy for RC. Relational capital efficiency (RCE) was measured as the ratio of marketing, selling and advertising expenses to VA. In addition, Nimtrakoon (2015), Xu \& Li (2019), Xu \& Wang (2019a) and Yao et al. (2019) also confirmed that the modified VAIC model with the introduction of RC is more accurate than the original VAIC model to measure IC.

In addition, Nadeem et al. (2019) made adjustments to the original VAIC model by replacing SC with innovation capital (measured through R\&D expenses). They also modified the calculation of VA by adding R\&D back. Bayraktaroglu et al. (2019) proposed an extended VAIC model with the introduction of innovation capital (measured by R\&D expenses) and customer capital (measured by sales, marketing and distribution expenses). They found that the proposed model performs better compared to the original VAIC model.

\subsection{IC and firm competitiveness and performance}

The competitiveness of a company results from possessing valuable and inimitable resources, which enables the firm to achieve a favorable competitive position to maintain its market position and get superior performance. Therefore, firms need to identify, maintain, and develop IC resources. Sanchez-Gutierrez et al. (2016) found that IC directly influences the competitiveness of manufacturing small and medium-sized enterprises (SMEs) in Mexico. Based on data from three countries (i.e. Finnish, Russian, and China), Kianto et al. (2013) argued that IC manage- 
ment influences company competitiveness positively, and competitiveness plays a mediating role between IC and performance.

Various studies have investigated the relationship between IC and firm performance, but there are still mixed results. An early study by Chen et al. (2005) showed that physical capital, HC, SC and R\&D expenditure positively affect firms' market value and return on assets (ROA). Based on the manufacturing firms in Thailand, Phusavat et al. (2011) found that IC can improve firm's performance measured by ROA, return on equity (ROE), revenue growth, and employee productivity. Pal \& Soriya (2012) found that profitability and IC are positively associated but no relationship exists between IC and productivity and market value in Indian pharmaceutical and textile industries. By adding an extra IC component (i.e. RC), Nimtrakoon (2015) found that firms with greater IC tend to have greater market value and better financial performance in ASEAN countries. CEE and HCE are observed to be the most contributors in value generation whereas SCE and RCE possess less importance. Based on the survey of 240 manufacturing companies, Andreeva \& Garanina (2016) documented that human and structural capitals positively affect corporate performance, while RC does not in the context of Russia. Recently, taking Korean manufacturing firms as the sample, Xu \& Wang (2018) argued that physical capital, HC and RC positively affect financial performance. Recently, for the Turkish manufacturing sector, Bayraktaroglu et al. (2019) proposed an extended VAIC model with the inclusion of customer capital and innovation capital, and found that SCE has a positive impact on firms' profitability and innovation capital efficiency has a direct impact on firms' productivity. Using the VAIC model, Mohapatra et al. (2019) found that only HC has a positive and significant impact on operating efficiency of Indian banks, whereas physical capital and SC hurt the efficiency. By choosing renewable energy enterprises in China, Xu \& Liu (2019) concluded that physical and human capitals are the most important components of IC to economic sustainable performance at different life cycle stages. Xu \& Wang (2019b), based on the original VAIC model, suggested that profitability is determined by physical capital and HCE, and companies' productivity is positively related to physical capital and negatively related to human resources.

\section{RESEARCH OBJECTIVE, METHODOLOGY AND DATA}

\subsection{Sample selection}

This study applies the modified and extended VAIC method and investigates the IC-performance relationship of manufacturing firms listed on the Korea Stock Exchange during 2013-2018. Data are collected from the DataGuide database for the relevant years. Firms with missing data, firms listed after the year 2013, and firms with debt ratio greater than 1 are excluded from our sample. Manufacturing firms have to release the financial statements for 6 consecutive years (2013-2018). Finally, 2,490 observations for 415 Korean manufacturing firms are used in the analysis. The regressions are carried out using Stata 14.

\subsection{Variables}

For dependent variable, firm performance is measured in three aspects, namely, profitability, productivity, and market value. ROA and ROE are for measuring profitability (Chen et al., 2005; 
Pal \& Soriya, 2012; Jordăo \& de Almeida, 2017; Sardo \& Serrasqueiro, 2017; Xu et al., 2017; Ginesti et al., 2018; Smriti \& Das, 2018; Xu \& Wang, 2018; Bayraktaroglu et al., 2019; Xu \& Liu, 2019; Xu \& Wang, 2019b), asset turnover ratio (ATO) is for productivity ( Pal \& Soriya, 2012; Dzenopoljac et al., 2017; Ginesti et al., 2018; Smriti \& Das, 2018; Bayraktaroglu et al., 2019; Xu \& Wang, 2019b), and market-to-book ratio (MB) is chosen for market value (Chen et al., 2005; Pal \& Soriya, 2012; Nimtrakoon, 2015; Dzenopoljac et al., 2017; Bayraktaroglu et al., 2019). The firm performance indicators are calculated as follows:

$\mathrm{RO} A=$ Net income/Average total assets

$\mathrm{ROE}=$ Net income $/$ Average shareholders' equity

$A T O=$ Total revenue/Average total assets

$M B=$ Market value of the firm/Book value of the firm

The modified and extended VAIC model in this current study is applied by adding two IC components, innovation capital and RC. R\&D expenses are chosen as a proxy for innovation capital, and marketing and advertising expenses are adopted to proxy for RC. Pulic (1998) calculated VA by adding labor costs and depreciation and amortization back to operating profit. He argued that spending on employees should be treated as investment rather than costs due to its long-term benefits to the firm. Based on this point of view, R\&D expenses and marketing and advertising expenses should also be added back. Therefore, the VA calculation in the new model is modified as follows:

$V A_{m}=$ Operating profit + Depreciation + Amortization + Employees' salaries and wages + Marketing and advertising expenses $+R \& D$ expenses

IC components in the new VAIC model-capital employed efficiency (CEEm), human capital efficiency (HCEm), structural capital efficiency (SCEm), innovation capital efficiency (RDEm), and relational capital efficiency (RCEm)-are calculated as follows:

$C E E_{m}=V A_{m} / C E$

$H C E_{m}=V A_{m} / H C$

$S C E_{m}=\left(V A_{m}-H C-R \& D\right.$ expenses-marketing and advertising expenses $) / V A_{m}$

$R D E_{m}=R \& D$ expenses $/ V A_{m}$

$R C E_{m}=$ Marketing and advertising expenses $/ V A_{m}$

In terms of control variables, firm size (Size) is the natural logarithm of total assets of the firm (Nimtrakoon, 2015; Sardo \& Serrasqueiro, 2017; Xu \& Wang, 2018, 2019b; Mohapatra et al., 2019; Xu \& Liu, 2019). Debt ratio (Lev) is the ratio of total liabilities to total assets (Nimtrakoon, 2015; Sardo \& Serrasqueiro, 2017, 2018; Xu \& Wang, 2018, 2019b; Xu \& Liu, 2019). Following prior studies (Xu et al., 2017; Nadeem et al., 2019; Xu \& Wang, 2019b), gross domestic product growth rate (GDP) is used to minimize external influences. A year dummy is included in our regression model. 


\subsection{Models}

Model 1 and 2 are used to determine IC components' impact on firm profitability.

$\mathrm{ROA} A \beta_{0}+\beta_{1} C E E_{m}+\beta_{2} \mathrm{HCE}_{m}+\beta_{3} S C E_{m}+\beta_{4} \mathrm{RDE}_{m}+\beta_{5} \mathrm{RCE}_{m}+\beta_{6}$ Size $+\beta_{7} L e v+\beta_{8} G D P+\sum Y e a r+\varepsilon$

$\mathrm{ROE}=\beta_{0}+\beta_{1} C \mathrm{EE}_{m}+\beta_{2} \mathrm{HCE}_{m}+\beta_{3} S C E_{m}+\beta_{4} \mathrm{RDE}_{m}+\beta_{5} \mathrm{RCE} \mathrm{E}_{m}+\beta_{6}$ Size $+\beta_{7} L e v+\beta_{8} G D P+\sum$ Year $+\varepsilon$

Model 3 is utilized to examine the impact of IC components on firm productivity.

$A T O=\beta_{0}+\beta_{1} C E E_{m}+\beta_{2} H C E_{m}+\beta_{3} S C E_{m}+\beta_{4} R D E_{m}+\beta_{5} R C E_{m}+\beta_{6} S_{i q e}+\beta_{7} L e v+\beta_{8} G D P+\sum$ Year $+\varepsilon$

Model 4 is applied to investigate the relationship between IC components and market value.

$M B=\beta_{0}+\beta_{1} C E E_{m}+\beta_{2} H C E_{m}+\beta_{3} S C E_{m}+\beta_{4} R D E_{m}+\beta_{5} R C E_{m}+\beta_{6}$ Size $+\beta_{7} L e v+\beta_{8} G D P+\sum$ Year $+\varepsilon$

where $\beta$ stands for the presumed parameters and $\varepsilon$ denotes the measurement error term.

\section{RESULTS AND DISCUSSION}

Table 1 demonstrates the descriptive statistics of performance measures and the modified and extended VAIC model's measures for 415 Korean manufacturing firms. The positive mean values of firm performance suggest that the manufacturing sector in South Korean has positive performance on average. Among IC efficiency values, $\mathrm{HCE}_{\mathrm{m}}$ has the highest mean value, which indicates human resources are crucial to manufacturing firms in the creation of value. This is in line with the findings of Xu \& Wang (2018, 2019a), Bayraktaroglu et al. (2019), and Xu \& Li (2019). The mean value of $\mathrm{SCE}_{\mathrm{m}}$ is 0.6593 . The contribution of innovation capital and RC for creating value is quite low. Table 1 also shows that the mean value of Size is 26.9255. Korean manufacturing firms have, on average, $39.84 \%$ of debt ratio. It is obvious that almost but ROA and ROE are positively skewed.

Tab. 1 - Descriptive statistics of the modified and extended VAIC model. Source: own research

\begin{tabular}{|l|l|l|l|l|l|l|l|}
\hline Variable & $\mathrm{N}$ & Mean & Max & Min & S.D. & Skewness & Kurtosis \\
\hline ROA & 2490 & 0.0347 & 0.2816 & -0.3202 & 0.0524 & -0.155 & 5.493 \\
\hline ROE & 2490 & 0.0559 & 0.7540 & -1.2672 & 0.1078 & -1.474 & 18.483 \\
\hline ATO & 2490 & 0.8861 & 2.8751 & 0.0206 & 0.4736 & 0.796 & 1.277 \\
\hline MB & 2490 & 1.0979 & 5.9493 & 0.2381 & 0.6094 & 3.034 & 13.236 \\
\hline CEEm & 2490 & 0.1594 & 1.2705 & -1.1015 & 0.1591 & 0.255 & 12.371 \\
\hline HCEm & 2490 & 4.0855 & 32.7035 & -15.3008 & 4.1798 & 1.332 & 7.468 \\
\hline SCEm & 2490 & 0.6593 & 5.0407 & -2.4723 & 0.4346 & 1.638 & 26.247 \\
\hline RDEm & 2490 & 0.0438 & 0.7711 & -0.3962 & 0.0931 & 2.801 & 12.163 \\
\hline RCEm & 2490 & 0.0591 & 0.9447 & -0.1956 & 0.1155 & 3.228 & 13.425 \\
\hline Size & 2490 & 26.9255 & 31.1009 & 24.1861 & 1.3170 & 0.897 & 0.627 \\
\hline Lev & 2490 & 0.3984 & 0.9369 & 0.0199 & 0.1886 & 0.099 & -0.703 \\
\hline GDP & 2490 & 0.0295 & 0.0334 & 0.0267 & 0.0021 & 0.622 & -0.523 \\
\hline
\end{tabular}


Table 2 shows the results of normality test. The study uses the Kolmogorov-Smirnov test, and the results indicate that the data are not normally distributed $(\mathrm{p}<0.05)$. This implies that further analysis should use Pearson's correlation coefficient analysis.

Tab. 2 - Normality tests. Source: own research

\begin{tabular}{|l|l|l|l|}
\hline Variable & Statistic & df & Sig. \\
\hline ROA & 0.109 & 2490 & 0.000 \\
\hline ROE & 0.157 & 2490 & 0.000 \\
\hline ATO & 0.058 & 2490 & 0.000 \\
\hline MB & 0.186 & 2490 & 0.000 \\
\hline CEEm & 0.127 & 2490 & 0.000 \\
\hline HCEm & 0.151 & 2490 & 0.000 \\
\hline SCEm & 0.190 & 2490 & 0.000 \\
\hline RDEm & 0.298 & 2490 & 0.000 \\
\hline RCEm & 0.268 & 2490 & 0.000 \\
\hline Size & 0.085 & 2490 & 0.000 \\
\hline Lev & 0.042 & 2490 & 0.000 \\
\hline GDP & 0.201 & 2490 & 0.000 \\
\hline
\end{tabular}

To test for multi-collinearity, an analysis of the variance inflation factor (VIF) was conducted. Individual VIF values greater than 10 indicate a multi-collinearity problem (Neter et al., 1989). It was observed that all VIF values vary between 1.004 and 3.096, which suggests that multicollinearity is not a serious concern in the current study. The correlation analysis results in Table 3 reveal that HCEm is positively associated with ROA, ROE and MB, while it is negatively associated with ATO. SCEm is positively associated with MB and negatively associated with ROE and ATO. RDEm and RCEm are positively associated with MB. CEEm is positively associated with the four performance indicators.

Tab. 3 - Correlation matrix. Source: own research

\begin{tabular}{|l|l|l|l|l|l|}
\hline Variable & CEEm & HCEm & SCEm & RDEm & RCEm \\
\hline ROA & $0.627 * * *$ & $0.601 * * *$ & -0.007 & 0.022 & -0.001 \\
\hline ROE & $0.719 * * *$ & $0.544 * * *$ & $-0.040 * *$ & $0.031 *$ & 0.011 \\
\hline ATO & $0.287 * * *$ & $-0.051^{* * *}$ & $-0.087 * * *$ & -0.00002 & $0.068^{* * *}$ \\
\hline MB & $0.196^{* * *}$ & $0.047 * * *$ & $0.038^{* *}$ & $0.071 * * *$ & $0.089 * * *$ \\
\hline
\end{tabular}

${ }^{*} \mathrm{p}<0.10,{ }^{* *} \mathrm{p}<0.05,{ }^{* * *} \mathrm{p}<0.01$.

Before the regression analysis, the Hausman test was applied to determine whether to use the fixed effect model or random effect model. In Table 4, p values of models (1)-(4) are significantly lower than 0.05 , the fixed effect model was employed in this study. 
Tab. 4 - Hausman test. Source: own research

\begin{tabular}{|l|l|l|}
\hline Model (1) & $\chi^{2}=65.92$ & Prob $>\chi^{2}=0.000$ \\
\hline Model (2) & $\chi^{2}=145.15$ & Prob $>\chi^{2}=0.000$ \\
\hline Model $(3)$ & $\chi^{2}=60.34$ & Prob $>\chi^{2}=0.000$ \\
\hline Model (4) & $\chi^{2}=70.46$ & Prob $>\chi^{2}=0.000$ \\
\hline
\end{tabular}

Table 5 shows the regression results of the original VAIC model, with model (2) having the highest explanatory power. The results show that, while HCE and SCE have positive impacts on profitability (i.e. ROA and ROE), they are not significant predictors of ATO and MB. CEE was found to be the significant predictor of firm performance, except the dependent variable MB.

Tab. 5 - Regression results of the original VAIC model. Source: own research

\begin{tabular}{|c|c|c|c|c|}
\hline Variable & Model (1) & Model (2) & Model (3) & Model (4) \\
\hline & $\mathrm{ROA}$ & ROE & ATO & MB \\
\hline Constant & $-0.837 * * *(-3.91)$ & $-0.855(-1.45)$ & $4.153^{* * *}(3.00)$ & $-2.403(-0.96)$ \\
\hline $\mathrm{CEE}$ & $0.189 * * *(7.59)$ & $0.636 * * *(13.58)$ & $0.471 * * *(4.99)$ & $0.005(0.05)$ \\
\hline HCE & $0.005^{* * *}(7.80)$ & $0.004 * * *(3.59)$ & $-0.002(-0.70)$ & $-0.005(-1.28)$ \\
\hline SCE & $0.005 *(1.86)$ & $0.009 * * *(3.05)$ & $0.010(0.78)$ & $0.056(1.25)$ \\
\hline Size & $0.027 * * *(3.63)$ & $0.028(1.39)$ & $-0.145^{* * *}(-3.08)$ & $0.180 * *(2.04)$ \\
\hline Lev & $-0.106 * * *(-5.99)$ & $-0.212 * * *(-5.86)$ & $0.293 * * *(3.02)$ & $0.066(0.34)$ \\
\hline GDP & $4.501 * * *(5.26)$ & $4.500 *(1.94)$ & $17.007 * *(2.35)$ & $-51.437 * * *(-4.27)$ \\
\hline Year & Included & Included & Included & Included \\
\hline Adj. R2 & 0.6735 & 0.7206 & 0.0017 & 0.0011 \\
\hline $\mathrm{F}$ & $57.65^{* * *}$ & $185.17 * * *$ & $12.12^{* * *}$ & $6.30 * * *$ \\
\hline $\mathrm{N}$ & 2490 & 2490 & 2490 & 2490 \\
\hline
\end{tabular}

${ }^{*} \mathrm{p}<0.10,{ }^{* *} \mathrm{p}<0.05,{ }^{* * *} \mathrm{p}<0.01 . \mathrm{t}$-values are in parentheses.

The results of a regression analysis for the modified and extended VAIC model are shown in Table 6, in which all models were found to be significant. Compared to the original VAIC model, entering RDEm and RCEm caused a slight increase in adjusted R2 values in the four models. According to the results of models (1) and (2), where ROA and ROE are the dependent variables, CEEm is the most influential contributor to firm profitability, which supports the study of Phusavat et al. (2011) of the Thai manufacturing industry. This means that the higher the CEE of a manufacturing firm is, the more profitable the firm can be.

The results in models (1) and (2) show that HCEm is positively related to ROA and ROE at the $1 \%$ level. The findings suggest that spending on employees should be treated as investment, and firms should effectively use these human resources to create more wealth. Conversely, Firer \& Williams (2003) argued that spending on employees is treated as expenditure by firms.

SCEm was found to have non-significant impacts on ROA and ROE when the new components (i.e. RDEm and RCEm) were introduced, a result consistent with Xu \& Wang (2018), 
who analyzed this correlation based on the data from 390 Korean manufacturing firms. This may be caused by the imperfect functioning of manufacturing sector in South Korea. However, Bayraktaroglu et al. (2019) collected data from Turkish manufacturing sector and found a positive relationship between SCE and ROA and ROE. Ting \& Lean (2009) and Mohapatra et al. (2019) documented a significant and negative impact of SC.

In addition, RDEm had a negative impact on the firm's profitability, consistent with the findings of Xu \& Wang (2018). Phusavat et al. (2011) and Bayraktaroglu et al. (2019) found a negative but insignificant relationship between innovation capital and firm profitability indicator (i.e. ROA and ROE). However, some IC studies (e.g. Chen et al., 2005; Chang \& Hsieh, 2011) have shown a positive relationship between innovation capital and financial performance indicators, namely, ROA and ROE. According to our results, the effect of RCEm on firm profitability was negative, whereas Xu \& Wang (2019a) argued that RCE is the most influencing factor to firm profitability. An increase in innovation capital and RC will lead to lower profitability. This result may be due to the fact that according to accounting standards, R\&D along with marketing and advertising expenditures are expensed when incurred, which reduces the current-year's profit. Chen et al. (2005) confirmed that RC hinders the profitability of listed companies in Taiwan. Andreeva \& Garanina (2017) also found that RC turns out to negatively influence organizational performance in Russia. The findings of Crema \& Verbano (2016) suggested that manufacturing SMEs have only moderately developed their RC. In addition, in 14 Western European countries, Sardo \& Serrasqueiro (2018) found that IC efficiency within a given period has a positive impact on the financial performance (measured through ROA) of high-, medium- and low-tech firms.

In model (3), only CEEm had a significant and positive impact on ATO, while the effect of the other IC components on ATO became insignificant at the 5\% level. Costa (2012) argued that firms with an efficient management of IC succeed in maximizing their performance and productivity in the Italian yacht manufacturing sector, one of the most competitive sectors. Bayraktaroglu et al. (2019) also found a positive relation between CEE and ATO and between RDEm and ATO. For Indian listed companies, Smriti and Das (2018) suggested that all three IC elements - CEE, HCE and SCE - have significant impacts on firm productivity.

The results of model (4) are similar to those of model (3). As RDEm and RCEm were included in the regression, IC components exerted non-significant impacts on MB. Chan (2009) also found no significant link between IC and productivity, profitability and market value for listed firms in Hong Kong. However, Ozturk \& Demirgunes (2007), Maditinos et al. (2011), and Bayraktaroglu et al. (2019) showed that HCE is the only significant predictor for MB. Seo (2019) pointed out that innovation capital has no impact on $\mathrm{MB}$, and $\mathrm{RC}$ has a positive impact for top 100 Korean manufacturing firms listed on the KOSPI. In the case of Arab region, Dzenopoljac et al. (2017) identified a negative relationship between CEE and HCE and the market value.

Of the control variables, firm size (Size) was positively significant with ROA and MB, and negatively significant with ATO. Lev had a positive impact on firm productivity and a negative impact on firm profitability. GDP had significant impacts on the performance measurements. 
Tab. 6 - Regression results of models (1)-(4) of the modified and extended VAIC model.

Source: own research

\begin{tabular}{|c|c|c|c|c|c|c|c|c|}
\hline \multirow{3}{*}{$\begin{array}{l}\text { Variable } \\
\text { Constant }\end{array}$} & \multicolumn{2}{|l|}{ Model (1) } & \multicolumn{2}{|l|}{ Model (2) } & \multicolumn{2}{|l|}{ Model (3) } & \multicolumn{2}{|l|}{ Model (4) } \\
\hline & \multicolumn{2}{|l|}{ ROA } & \multicolumn{2}{|l|}{ ROE } & \multicolumn{2}{|l|}{ ATO } & \multicolumn{2}{|l|}{$\mathrm{MB}$} \\
\hline & $\begin{array}{l}-0.852^{* * *} \\
(-3.93)\end{array}$ & $\begin{array}{l}-0.813^{* * *} \\
(-4.21)\end{array}$ & $\begin{array}{l}-0.915 \\
(-1.54)\end{array}$ & $\begin{array}{l}-0.870 \\
(-1.50)\end{array}$ & $\begin{array}{l}4.103^{* * *} \\
(2.95)\end{array}$ & $\begin{array}{l}4.153^{* * *} \\
(2.99)\end{array}$ & $\begin{array}{l}-2.401 \\
(-0.96)\end{array}$ & $\begin{array}{l}-2.380 \\
(-0.95)\end{array}$ \\
\hline CEEm & $\begin{array}{l}0.189 * * * \\
(7.65)\end{array}$ & $\begin{array}{l}0.184 * * * \\
(7.58)\end{array}$ & $\begin{array}{l}0.637 * * * \\
(13.86)\end{array}$ & $\begin{array}{l}0.632^{* * *} \\
(13.65)\end{array}$ & $\begin{array}{l}0.474 * * * \\
(5.05)\end{array}$ & $\begin{array}{l}0.468^{* * * *} \\
(5.04)\end{array}$ & $\begin{array}{l}0.017 \\
(0.17)\end{array}$ & $\begin{array}{l}0.015 \\
(0.15)\end{array}$ \\
\hline HCEm & $\begin{array}{l}0.005^{* * *} \\
(7.80)\end{array}$ & $\begin{array}{l}0.005^{* * *} \\
(8.05)\end{array}$ & $\begin{array}{l}0.004^{* * *} \\
(3.59)\end{array}$ & $\begin{array}{l}0.004^{* * *} \\
(3.64)\end{array}$ & $\begin{array}{l}-0.002 \\
(-0.74)\end{array}$ & $\begin{array}{l}-0.002 \\
(-0.73)\end{array}$ & $\begin{array}{l}-0.005 \\
(-1.20)\end{array}$ & $\begin{array}{l}-0.005 \\
(-1.19)\end{array}$ \\
\hline SCEm & $\begin{array}{l}0.004 \\
(1.62) \\
\end{array}$ & $\begin{array}{l}-0.002 \\
(-0.82) \\
\end{array}$ & $\begin{array}{l}0.009 * * * \\
(2.86)\end{array}$ & $\begin{array}{l}0.001 \\
(0.45)\end{array}$ & $\begin{array}{l}0.010 \\
(0.72)\end{array}$ & $\begin{array}{l}0.002 \\
(0.17) \\
\end{array}$ & $\begin{array}{l}0.062 \\
(1.28) \\
\end{array}$ & $\begin{array}{l}0.058 \\
(1.02) \\
\end{array}$ \\
\hline RDEm & & $\begin{array}{l}-0.071 * * * \\
(-4.91)\end{array}$ & & $\begin{array}{l}-0.094^{* * *} \\
(-3.53)\end{array}$ & & $\begin{array}{l}-0.099 \\
(-0.92)\end{array}$ & & $\begin{array}{l}-0.054 \\
(-0.27)\end{array}$ \\
\hline RCEm & & $\begin{array}{l}-0.075^{* * *} \\
(-3.69)\end{array}$ & & $\begin{array}{l}-0.074 * * \\
(-2.00)\end{array}$ & & $\begin{array}{l}-0.086 \\
(-0.87) \\
\end{array}$ & & $\begin{array}{l}-0.222 \\
(-0.11) \\
\end{array}$ \\
\hline Size & $\begin{array}{l}0.028^{* * *} \\
(3.64)\end{array}$ & $\begin{array}{l}0.027 * * * \\
(3.97)\end{array}$ & $\begin{array}{l}0.030 \\
(1.47)\end{array}$ & $\begin{array}{l}0.029 \\
(1.47)\end{array}$ & $\begin{array}{l}-0.144 * * * \\
(-3.03)\end{array}$ & $\begin{array}{l}-0.145^{* * *} \\
(-3.06)\end{array}$ & $\begin{array}{l}0.180^{* *} \\
(2.04)\end{array}$ & $\begin{array}{l}0.180^{* *} \\
(2.03)\end{array}$ \\
\hline Lev & $\begin{array}{l}-0.112^{* * *} \\
(-6.14)\end{array}$ & $\begin{array}{l}-0.103^{* * *} \\
(-6.45)\end{array}$ & $\begin{array}{l}-0.229 * * * \\
(-6.35)\end{array}$ & $\begin{array}{l}-0.219 * * * \\
(-6.50)\end{array}$ & $\begin{array}{l}0.281 * * * \\
(2.88)\end{array}$ & $\begin{array}{l}0.292^{* * *} \\
(3.05)\end{array}$ & $\begin{array}{l}0.070 \\
(0.35)\end{array}$ & $\begin{array}{l}0.074 \\
(0.38)\end{array}$ \\
\hline GDP & $\begin{array}{l}4.632^{* * * *} \\
(5.35)\end{array}$ & $\begin{array}{l}4.448^{* * *} \\
(5.28) \\
\end{array}$ & $\begin{array}{l}4.872^{* *} \\
(2.08)\end{array}$ & $\begin{array}{l}4.605^{* *} \\
(1.98) \\
\end{array}$ & $\begin{array}{l}17.263^{* *} \\
(2.38) \\
\end{array}$ & $\begin{array}{l}16.991^{* *} \\
(2.32)\end{array}$ & $\begin{array}{l}-51.634^{* * *} \\
(-4.31)\end{array}$ & $\begin{array}{l}-51.808^{* * *} \\
(-4.32) \\
\end{array}$ \\
\hline Year & Included & Included & Included & Included & Included & Included & Included & Included \\
\hline Adj. $\mathrm{R}^{2}$ & 0.6678 & 0.6878 & 0.7179 & 0.7225 & 0.0021 & 0.0032 & 0.0012 & 0.0013 \\
\hline $\mathrm{F}$ & $56.31 * * *$ & $54.84 * * *$ & $179.01 * * *$ & $166.45^{* * *}$ & $12.13^{* * *}$ & $10.72^{* * *}$ & $6.28^{* * *}$ & $5.32 * * *$ \\
\hline $\mathrm{N}$ & 2490 & 2490 & 2490 & 2490 & 2490 & 2490 & 2490 & 2490 \\
\hline
\end{tabular}

${ }^{*} \mathrm{p}<0.10,{ }^{* *} \mathrm{p}<0.05,{ }^{* * *} \mathrm{p}<0.01 . \mathrm{t}$-values are in parentheses.

\section{CONCLUSION}

This study investigates whether IC and its components affect firm performance in manufacturing sector in South Korea. It also compares the regression results of the original VAIC method with the results of the modified and extended VAIC method. Based on our results, the modified and extended VAIC model performs better than the original VAIC model. The findings contribute to the IC literature, suggesting that IC is a key driver in creating value in manufacturing firms in the Korean context. In addition, CEEm contributes most to performance of the Korean manufacturing firms. HCEm positively influences firm profitability measured by ROA and ROE, while RDEm and RCEm have negative impacts. SCEm was observed to have no significant impact on firm performance.

This study can help managers review the performance of manufacturing firms through the management of their IC resources to sustain business operation over time. This study uses the modi- 
fied and extended VAIC method to more specifically investigate how the performance of Korean manufacturing firms might be improved through IC. The study reveals that the modified and extended VAIC model can be employed with confidence to accurately measure IC. This study also fills a gap by using data from South Korea, an emerging economy where the manufacturing sector has been undergoing industrial transformation.

Managers in the Korean manufacturing sector should place great emphasis on the role of physical and financial capital. They need to invest more in their HC through continuous learning and training. The insignificant impacts of SC reveal that manufacturing firms should devote attention to developing SC by maintaining a clear knowledge strategy, implementing information systems and tools, constructing an innovative organizational culture along with related steps. Meanwhile, manufacturing firms should construct technological innovation networks to improve their technology innovation capabilities through various initiatives. In addition, good social network relationships with their customers as well as suppliers should be established to build the corporate image.

This paper has some limitations. First, the lagged effect of IC components on firm performance was not taken into consideration. Prior studies (e.g. Tran \& Vo, 2018; Xu \& Wang, 2019b) have shown that IC components have a several-year lagged effect on firm performance. Second, other industries should be included to compare these with the manufacturing industry. Further, the results of this paper could also be compared with studies from other countries or regions.

\section{Acknowledgements}

The research for this paper was financially supported by the Soft Science Research Plan of Shandong Province (Grant Number 2019RKB01222). The second author (Feng Liu) is the corresponding author of this paper.

\section{References}

1. Ahangar, R. G. (2011). The relationship between intellectual capital and financial performance: An empirical investigation in an Iranian company. African Journal of Business Management, 5 (1), 88-95. https://doi.org/10.5897/AJBM10.712

2. Andreeva, T., \& Garanina, T. (2016). Do all elements of intellectual capital matter for organizational performance? Evidence from Russian context. Journal of Intellectual Capital, 17 (2), 397-412. https://doi.org/10.1108/jic-07-2015-0062

3. Andreeva, T., \& Garanina, T. (2017). Intellectual Capital and Its Impact on the Financial Performance of Russian Manufacturing Companies. Foresight and STI Governance, 11 (1), 31-40. http://dx.doi.org/10.17323/2500-2597.2017.1.31.40.

4. Bayraktaroglu, A. E., Calisir, F., \& Baskak, M. (2019). Intellectual capital and firm performance: an extended VAIC model. Journal of Intellectual Capital, 20 (3), 406-425. https:// doi.org/10.1108/jic-12-2017-0184

5. Behun M., Gavurova B., Tkacova A., \& Kotaskova A. (2018). The impact of the manufacturing industry on the economic cycle of European Union countries. Journal of Competitiveness, 10 (1), 23-39. https://doi.org/10.7441/joc.2018.01.02

6. Bontis, N. (1998). Intellectual capital: an exploratory study that develops measures and models. Management decision, 36 (2), 63-76. https://doi.org/10.1108/00251749810204142 
7. Brooking, A. (1996). Intellectual Capital: Core Asset for the New Millennium Enterprise. London: International Thomson Business Press.

8. Chan, K. H. (2009). Impact of intellectual capital on organizational performance: An empirical study of companies in the Hang Seng Index (part 1). The Learning Organization, 16 (1), 4-21. https://doi.org/10.1108/09696470910927641

9. Chang, S. L. (2007). Valuing Intellectual Capital and Firms' Performance: Modifying Value Added Intellectual Coefficient (VAICTM) in Taiwan IT Industry. PhD thesis, Golden Gate University, San Francisco, CA.

10. Chang, W. S., \& Hsieh, J. J. (2011). Intellectual capital and value creation-is innovation capital a missing link? International Journal of Business and Management, 6 (2), 3-12. https://doi. org/10.5539/ijbm.v6n2p3

11. Chen, M. C., Cheng, S. J., \& Hwang, Y. (2005). An empirical investigation of the relationship between intellectual capital and firms' market value and financial performance. Journal of Intellectual Capital, 6 (2), 159-176. https://doi.org/10.1108/14691930510592771

12. Cisneros, M. A. I., \& Hernandez-Perlines, F. (2018). Intellectual capital and Organization performance in the manufacturing sector of Mexico. Management Decision, 56 (8), 1818-1834. https://doi.org/10.1108/md-10-2017-0946

13. Clarke, M., Seng, D., \& Whiting, R. H. (2011). Intellectual capital and firm performance in Australia. Journal of Intellectual Capital, 12 (4), 505-530. https://doi. org $/ 10.1108 / 14691931111181706$

14. Costa, R. (2012). Assessing Intellectual Capital efficiency and productivity: An application to the Italian yacht manufacturing sector. Expert Systems with Applications, 39 (8), 7255-7261. https://doi.org/10.1016/j.eswa.2012.01.099

15. Crema, M., \& Verbano, C. (2016). Managing Intellectual Capital in Italian Manufacturing SMEs. Creativity and Innovation Management, 25 (3), 408-421.

16. Delgado-Verde, M., Martín-de Castro, G., \& Amores-Salvadó, J. (2016). Intellectual capital and radical innovation: Exploring the quadratic effects in technology-based manufacturing firms. Technovation, 54, 35-47.

17. Dzenopoljac, V., Yaacoub, C., Elkanj, N., \& Bontis, N. (2017). Impact of intellectual capital on corporate performance: evidence from the Arab region. Journal of Intellectual Capital, 18 (4), 884-903. https://doi.org/10.1111/caim.12074

18. Edvinsson, L., \& Malone. M. S. (1997). Intellectual Capital: Realizing Your Company's True Value by Finding Its Hidden Brainpower. New York: Harper Business.

19. Firer, S., \& Williams, S. M. (2003). Intellectual capital and traditional measures of corporate performance. Journal of Intellectual Capital, 4 (3), 348-360. https://doi. org $/ 10.1108 / 14691930310487806$

20. Fukao, K., Ikeuchi, K., Kim, Y., Kwon, H. U., \& Makino, T. (2016). International Competitiveness: A comparison of the Manufacturing sectors in Korea and Japan. Seoul Journal of Economics, 29, 43-68.

21. Ginesti, G., Caldarelli, A., \& Zampella, A. (2018). Exploring the impact of intellectual capital on company reputation and performance. Journal of Intellectual Capital, 19 (5), 915-934. https:// 
doi.org/10.1108/jic-01-2018-0012

22. Herrmann, C., Schmidt, C., Kurle, D., Blume, S., \& Thiede, S. (2014). Sustainability in manufacturing and factories of the future. International Journal of Precision Engineering and Manufacturing-Green Technology, 1 (4), 283-292. https://doi.org/10.1007/s40684-014-0034-z

23. Ho, C. A., \& Williams, S. M. (2003). International comparative analysis of the association between board structure and the efficiency of value added by a firm from its physical capital and intellectual capital resources. The International Journal of Accounting, 38 (4), 465-491. https:// doi.org/10.1016/j.intacc.2003.09.001

24. Hsu, W. H., \& Chang, Y. L. (2011). Intellectual capital and analyst forecast: evidence from the high-tech industry in Taiwan. Applied Financial Economics, 21 (15), 1135-1143. https://doi.org/1 $0.1080 / 09603107.2011 .564129$

25. Jelínková, E., \& Jiřincová, M. (2015). Diversity management as a tool of managing intellectual capital. Journal of Competitiveness, 7 (4), 3-17. https:// doi.org/10.7441/joc.2015.04.01

26. Jordão, R. V. D., \& Almeida, V. R. D. (2017). Performance measurement, intellectual capital and financial sustainability. Journal of Intellectual Capital, 18 (3), 643-666. https://doi. org/10.1108/jic-11-2016-0115

27. Kianto, A., Andreeva, T., \& Pavlov, Y. (2013). The impact of intellectual capital management on company competitiveness and financial performance. Knowledge Management Research \& Practice, 11 (2), 112-122. https://doi.org/10.1057/kmrp.2013.9

28. Maditinos, D., Chatzoudes, D., Tsairidis, C., \& Theriou, G. (2011). The impact of intellectual capital on firms' market value and financial performance. Journal of Intellectual Capital, 12 (1), 132-151. https://doi.org/10.1108/14691931111097944

29. Marr, B., Gray, D., \& Neely, A. (2003). Why do firms measure their intellectual capital? Journal of Intellectual Capital, 4 (4), 441-464. https://doi.org/10.1108/14691930310504509

30. Mohapatra, S., Jena, S. K., Mitra, A., \& Tiwari, A. K. (2019). Intellectual capital and firm performance: evidence from Indian banking sector. Applied Economics, 51 (57), 6054-6067. https://doi.org/10.1080/00036846.2019.1645283

31. Molodchik, M., \& Jardon, C. M. (2017). Intellectual capital as enhancer of product novelty: An empirical study of Russian manufacturing SMEs. Journal of Intellectual Capital, 18 (2), 419-436. https://doi.org/10.1108/jic-06-2016-0059

32. Nadeem, M., Dumay, J., \& Massaro, M. (2019). If you can measure it, you can manage it: a case of intellectual capital. Australian Accounting Review, 29 (2), 395-407. https://doi. org/10.1111/auar.12227

33. Nazari, J. A., \& Herremans, I. M. (2007). Extended VAIC model: measuring intellectual capital components. Journal of Intellectual Capital, 8 (4), 595-609. https://doi. $\operatorname{org} / 10.1108 / 14691930710830774$

34. Neter, J., Wasserman, W., \& Kutner, M. H. (1989). Applied Linear Regression Models. Homewood: Irwin Press.

35. Ngah, R., \& Ibrahim, A. R. (2012). The relationship of intellectual capital, innovation and organizational performance: a preliminary study in Malaysian SMEs. Advances in Global Business Research, 1 (1), 1-14. 
36. Nimtrakoon, S. (2015). The relationship between intellectual capital, firms' market value and financial performance: Empirical evidence from the ASEAN. Journal of Intellectual Capital, 16 (3), 587-618. https://doi.org/10.1108/jic-09-2014-0104

37. Ozturk, M. B., \& Demirgunes, K. (2007). Determination of effect of intellectual capital on firm value via value added intellectual coefficient methodology: an empirical study on ISElisted manufacturing firms. Istanbul Stock Exchange Review, 10 (37), 59-78.

38. Pal, K., \& Soriya, S. (2012). IC performance of Indian pharmaceutical and textile industry. Journal of Intellectual Capital, 13 (1), 120-137. https://doi.org/10.1108/14691931211196240

39. Phusavat, K., Comepa, N., Sitko-Lutek, A., \& Ooi, K. B. (2011). Interrelationships between intellectual capital and performance: Empirical examination. Industrial Management \& Data Systems, 111 (6), 810-829. https://doi.org/10.1108/02635571111144928

40. Pulic, A. (1998). Measuring the Performance of Intellectual Potential in Knowledge Economy. In 2nd McMaster World Congress on Measuring and Managing Intellectual Capital, McMaster University, Hamilton.

41. Sanchez-Gutierrez, J., Mejia-Trejo, J., Vargas-Barraza, J. A., \& Vazquez-Avila, G. (2016). Intellectual capital, impact factor on competitiveness: manufacturing industry SMEs in Mexico. Measuring Business Excellence, 20 (1), 1-11. https://doi.org/10.1108/MBE-12-2015-0059

42. Sardo, F., \& Serrasqueiro, Z. (2017). A European empirical study of the relationship between firms' intellectual capital, financial performance and market value. Journal of Intellectual Capital, 18 (4), 771-788. https://doi.org/10.1108/jic-10-2016-0105

43. Sardo, F., \& Serrasqueiro, Z. (2018). Intellectual capital, growth opportunities, and financial performance in European firms: Dynamic panel data analysis. Journal of Intellectual Capital, 19 (4), 747-767. https://doi.org/10.1108/JIC-07-2017-0099

44. Seo, S. H. (2019). The Effect of Intellectual Capital on Firms' Market Value and Financial Performance-Focused on VAIC Theory. Master's Dissertation, Pusan National University, Korea.

45. Smriti, N., \& Das, N. (2018). The impact of intellectual capital on firm performance: a study of Indian firms listed in COSPI. Journal of Intellectual Capital, 19 (5), 935-964. https://doi. org/10.1108/jic-11-2017-0156

46. Ståhle, P., Ståhle, S., \& Aho, S. (2011). Value added intellectual coefficient (VAIC): a critical analysis. Journal of Intellectual Capital, 12 (4), 531-551. https://doi. org/10.1108/14691931111181715

47. Stewart, T. A. (1997). Intellectual Capital: The New Wealth of Organizations. New York: Doubleday.

48. St-Pierre, J., \& Audet, J. (2011). Intangible assets and performance: Analysis on manufacturing SMEs. Journal of Intellectual Capital, 12 (2), 202-223. https://doi.org/10.1108/14691931111123395

49. Sveiby, K. E. (1997). The New Organizational Wealth: Managing and Measuring Knowledge-Based Assets. San Francisco: Berrett-Koehler Publishers.

50. Swart, J. (2006). Intellectual capital: disentangling an enigmatic concept. Journal of Intellectual Capital, 7 (2), 136-159. https://doi.org/10.1108/14691930610661827 
51. Ting, I. W. K., \& Lean, H. H. (2009). Intellectual capital performance of financial institutions in Malaysia. Journal of Intellectual Capital, 10 (4), 588-599. https://doi. org $/ 10.1108 / 14691930910996661$

52. Tran, D. B., \& Vo, D. H. (2018). Should bankers be concerned with Intellectual capital? A study of the Thai banking sector. Journal of Intellectual Capital, 19 (5), 897-914. https://doi. org/10.1108/jic-12-2017-0185

53. Vishnu, S., \& Gupta, V. K. (2014). Intellectual capital and performance of pharmaceutical firms in India. Journal of Intellectual Capital, 15 (1), 83-99. https://doi.org/10.1108/jic-04-20130049

54. Xu, J., \& Li, J. S. (2019). The impact of intellectual capital on SMEs' performance in China. Journal of Intellectual Capital, 20 (4), 448-509. https://doi.org/10.1108/jic-04-2018-0074

55. Xu, J., \& Sim, J. W. (2018). Characteristics of corporate R\&D investment in emerging markets: Evidence from manufacturing industry in China and South Korea. Sustainability, 10 (9), 3002. https://doi.org/10.3390/su10093002

56. Xu, J., \& Wang, B. H. (2018). Intellectual capital, financial performance and companies' sustainable growth: Evidence from the Korean manufacturing industry. Sustainability, 10 (12), 4651. https://doi.org/10.3390/su10124651

57. Xu, J., \& Wang, B. H. (2019a). Intellectual Capital Performance of the Textile Industry in Emerging Markets: A Comparison with China and South Korea. Sustainability, 11 (8), 2354. https://doi.org/10.3390/su11082354

58. Xu, J., \& Wang, B. H. (2019b). Intellectual capital and financial performance of Chinese agricultural listed companies. Custos e Agronegocio On Line, 15 (1), 273-290.

59. Xu, X. L., \& Liu, C. K. (2019). How to keep renewable energy enterprises to reach economic sustainable performance: from the views of intellectual capital and life cycle. Energy, Sustainability and Society, 9 (1), 7. https://doi.org/10.1186/s13705-019-0187-2

60. Xu, X. L., Yang, X. N., Zhan, L., Liu, C. K., \& Hu, M. M. (2017). Examining the relationship between intellectual capital and performance of listed environmental protection companies. Environmental Progress \& Sustainable Energy, 36 (4), 1056-1066. https://doi.org/10.1002/ep.12572

61. Yao, H. X., Haris, M., Tariq, G., Javaid, H. M., \& Khan, M. A. S. (2019). Intellectual Capital, Profitability, and Productivity: Evidence from Pakistani Financial Institutions. Sustainability, 11 (14), 3842. https://doi.org/10.3390/su11143842

\section{Contact information}

Jian Xu, Ph.D.

Qingdao Agricultural University

School of Management

Qingdao

China

E-mail:jianxusword@qau.edu.cn

ORCID: 0000-0002-0350-5202
Feng Liu, Ph.D. (Corresponding author)

Korea University Business School

Department of Logistics, Service and Operations

Management

Seoul

South Korea

E-mail:fenglsom@gmail.com

ORCID: 0000-0001-9367-049X 